\title{
Local knowledge and socio-economic determinants of traditional medicines' utilization in livestock health management in Southwest Nigeria
}

\author{
Taiwo E Mafimisebi ${ }^{1 *}$, Adegboyega E Oguntade ${ }^{1}$, Adebowale N Fajemisin ${ }^{2}$ and Olaiya P Aiyelari ${ }^{3}$
}

\begin{abstract}
Smallholder livestock farmers in Nigeria utilize traditional medicines derived from medicinal plants (PMs) for the maintenance of their animals' health. This study was designed to determine the PMs used in the study area and their level of utilization by livestock farmers, compare the level of utilization of PMs across the three states surveyed and identify the socio-economic factors influencing farmer's utilization of PMs. Thirty-five PMs were identified. Farmers had considerable knowledge about the identified PMs but about $80.0 \%$ of them used the PMs to poor/moderate extent. There were statistical differences in the utilization level of PMs among the three states. Six socio-economic variables were found to be statistically significant in influencing PMs' utilization. Farmer's age, household size, distance to the nearest veterinary hospital/clinic and extent of travels, had positive effects while negative effects were exhibited by farm income and number of heads of livestock. It was concluded that there was considerable knowledge about PMs and that utilization of PMs varied between the three states. It was recommended that local knowledge of PMs be preserved in the study area through screening and documentation.
\end{abstract}

Keywords: Medicinal Plants, Livestock, Health Management, Local Knowledge, Determinants, Utilization, Nigeria

\section{Introduction}

The Nigerian livestock industry is performing below expectation in its role of providing adequate animal proteins for the growing population. While annual population growth rate is about $3.0 \%$, the estimated annual growth rate of the outputs of the major livestock products is nearly stagnant. Also, the contribution of the livestock sub-sector to the Gross Domestic Product (GDP) has been declining [1-3]. This poor performance of the Nigerian livestock industry is in spite of an estimated livestock population of about 600 million [1]. The per capita animal protein intake is below 7.0 g per day [4-7]. With reference to the $35.0 \mathrm{~g}$ of animal protein per caput per day recommended by FAO, the shortfall in minimum protein requirements is about $89.0 \%[7,8]$. In fact, by the year 2020 when the Nigerian population is

\footnotetext{
*Correspondence: temafis@yahoo.com

'Department of Agricultural Economics and Extension, The Federal University of Technology, Akure, Nigeria

Full list of author information is available at the end of the article
}

expected to be about 230 million, a quantum leap in livestock production is required if the seemingly formidable problem of protein malnutrition is to be surmounted.

It is a general consensus that the generic problem of low productivity of the existing livestock population is the factor responsible for Nigeria meeting just about $50.0 \%$ of her per capita demand for animal proteins from domestic sources [6]. Associated with this generic problem are specific constraints which include the traditional animal rearing system characterized by low productivity, high mortality rate, low growth rate, prevalence of pests and diseases and other factors which render efficient use of resources impossible $[2,6]$.

The problems of pests and diseases and high mortality rates necessitate that health issues in traditional livestock management be tackled decisively for a successful livestock development programme in Nigeria. This is necessary because researchers have found out that healthcare expenses constitute close to $20 \%$ of the production cost of livestock in Nigeria [2,7]. Since the

\section{Biomed Central}


massive devaluation of the Nigerian naira in June, 1986, the currency has been losing value leading to increases in the prices of agricultural inputs, especially veterinary drugs, which are usually imported. The consequence of this is that poor livestock farmers were priced out of the market for imported inputs [6]. In three out of the five ecological zones in Nigeria, all (100\%) of the sampled farmers rated high cost of veterinary drugs as an important constraint to livestock production [9]. The high prices of inputs are the main cause of the collapse of many commercial livestock concerns. Smallholder livestock farmers were then left with the option of using more of PMs in managing the health of their animals to that livestock production can remain competitive [10].

According to McCorkle [11,12], "the fact remains incontrovertible that from time immemorial, traditional stock raisers; farmers and herders, have developed and perfected their own ways of managing the health of their stock thereby keeping them productive". Traditional livestock keepers were reported to treat and prevent livestock diseases using age-long home remedies, surgical and manipulative techniques, husbandry strategies and magico-religious practices [12]. The totality of these indigenous local animal healthcare beliefs and practices is what is popularly referred to in the literature as ethno-veterinary medicine [11].

Nigeria, like any other typical tropical country, is a paradise of parasites [13]. Though the nation's livestock population seems numerous, the health hazards and high mortality rates due to various diseases and parasitic infestations have been a vital and serious threat to livestock development [2]. About 95\% of the livestock in Nigeria are owned by the rural farmers. These farmers are mostly without western education and generally trapped in poverty. Most of them cannot appreciate the importance of modern veterinary healthcare in livestock management. Where they do, they probably cannot afford the prohibitive costs of the services some of which are being provided by quack veterinary personnel. This is probably responsible for the higher incidence of pests and diseases and mortality rates in the livestock managed by rural compared with peri-urban and urban farmers [8,14-16].

There are remarkable drawbacks of traditional medicines emanating from locally available medicinal plants (henceforth PMs) in terms of their preparation, efficacy, disease diagnosis and treatment specifications [17]. Despite this, their potential in the management and rearing of livestock in low-income developing countries cannot be denied [17]. According to McCorkle [12], the effective remedies and practices have several areas of high point compared with western drugs. They are cheaper because the important raw materials (plants) are obtained at no cost. In addition, they are more accessible and more readily understood. They also have a higher degree of environmental friendliness and are often more socio-culturally acceptable and better adapted to local realities.

A medicinal plant is any plant, which in one or more of its organs, contains substances that can be used for therapeutic purposes or which are precursors for the synthesis of useful drugs [18]. According to Ogunlela [19], "numerous plant species have several medicinal uses and perhaps, there is hardly any plant known to man that has no use in medicine." Ogunlela [19] also argued that most of the drugs that feature in pharmaceutical industry derive their origin from one or more plant products with different plant parts having different uses in the treatment of human and animal ailments. Medicinal plants are then best described as the bedrock of the pharmaceutical industry. This is probably the reason why medicinal plants are assuming increasing importance and relevance in various communities, especially in developing countries such as Nigeria. It is in these parts of the world that the curative effects of the various parts of such plants are most appreciated [19]. In rural areas of developing countries, probably the only avenue for healthcare delivery and treatment of sick humans and livestock is the practice of traditional medicines derived mostly from medicinal plants [20].

The extent of knowledge and utilization of PMs differ according to the culture and prevailing socio-economic conditions of users. Thus, it is important to provide empirical answers to questions like when and why do farmers use traditional medicines in the management of their stock health. Worldwide, adoption of improved livestock health management practices and the relationship between the adoption behaviour of farmers and farmers' characteristics have been studied [7,21-25]. In Nigeria, however, the actual extent of use of traditional medicines derived from medicinal plants as well as factors responsible for differences in their utilization among farmers in same and/or different localities have been sparingly explored. A careful investigation into this will contribute to improving Nigeria's livestock health management policies. This will help ensure the sustainability of livestock production and guarantee increased supply of affordable animal proteins. This study is therefore directed at (i) identifying PMs being used by farmers in livestock health management, (ii) determining the extent to which the identified PMs are being utilized by farmers, (iii) comparing the extent of use of PMs between farmers in identified locations of the study area, and (iv) investigating the relationship, if any, between farmers' socio-economic characteristics and their utilization of PMs.

\section{Methods}

\section{Study Area, Sampling and Data Collection}

The study was carried out in Southwest Nigeria. Nigeria lies on $10^{\circ} 0^{\prime} 0^{\prime \prime} \mathrm{N}$ latitude and $8^{\circ} 0^{\prime} 0^{\prime \prime} \mathrm{E}$ longitude. 
Farming is a major source of livelihood to the people of the Southwest Nigeria [26]. Traditional livestock rearing, especially small ruminants and poultry, is an important agricultural enterprise in the region. Data were gathered by administering a structured questionnaire on livestock farmers in one purposively selected Local Government Area (LGA) in three (Ondo, Ogun and Oyo) out of the six states in the region. The selection of these states was based on the fact that they had the highest number of registered farmers in Southwest Nigeria. Okitipupa LGA was selected in Ondo State, Iddo LGA was selected in Oyo State while Odeda LGA was selected in Ogun State. The LGAs were purposively selected based on the fact that they were previously hosts to farm settlement schemes. The farm settlement schemes were government sponsored agricultural programmes aimed at attracting young and educated persons into commercial agriculture. Most of them were established in the late 1960s. The existence of farm settlement schemes in these LGAs is expected to have exposed the farmers to veterinary drugs for animal health management and, hence, the farmers should be able to compare them with traditional medicine for managing animal health. Based on information supplied by the Agricultural Development Project (ADP) office of each state on the number of registered livestock farmers, three (3) communities with the highest number of registered livestock farmers were selected from each LGA. From each community, twenty (20) farmers were selected for interview by simple random sampling. Only farmers rearing small and large ruminants were targeted for the study. Data were gathered from the sample farmers using questionnaire.

The development of the interview schedule took place in two phases. In the first phase, an interview schedule with open-ended questions was used to identify the most viable PMs being used in the study area through extensive field visits, key informant interviews and focus group discussions (FGDs). The identified PMs were listed in a structured interview schedule for final administration.

A total of 180 farmers were selected for interview. However only 120 set of questionnaire contained adequate information for analysis. The set of 120 questionnaire is distributed as follows: Okitipupa LGA, 38; Iddo LGA, 34 and Odeda LGA, 48.

\section{Data Analysis}

The analytical tools used included descriptive statistics such as frequency tables, percentages, inferential statistics and regression model. The extent of use of PMs was expressed by the use of a five-point rating scale with the scoring order of 5,4,3,2 and 1 for frequently used (FU), occasionally used (OU), rarely used (RU), aware but not used (ANU) and not aware (NA), respectively. Two methods of computation were employed in capturing the utilization of PMs. The first one is the PM Use Index (PMUI). Following from Islam and Kashem [27], the PMUI for each PM was calculated as follows.

$$
\text { PMUI }=\mathrm{N}_{1} \times 5+\mathrm{N}_{2} \times 4+\mathrm{N}_{3} \times 3+\mathrm{N}_{4} \times 2+\mathrm{N}_{5} \times 1
$$

Where

PMUI is as already defined

$\mathrm{N}_{1}=$ No of farmers using PMs frequently

$\mathrm{N}_{2}=$ No of farmers using PMs occasionally

$\mathrm{N}_{3}=$ No of farmers using PMs rarely

$\mathrm{N}_{4}=$ No of farmers aware of but not using PMs

$\mathrm{N}_{5}=$ No of farmers not aware of PMs

The PMUIs were also used to rank the PMs in terms of their use.

The second represents the use of PMs by individual farmers. This level of utilization of PMs for each respondent farmer was calculated by adding up the scores obtained by the farmer in all the identified PMs compiled for the study. The scores obtained by the farmers were categorized into low user (55-90), moderate user (91-126) and high user (127-162) and presented in a frequency distribution.

The z-test was used to examine whether or not there was significant difference in the level of use of PMs between farmers in a pair of states among the three states covered in the survey. The formula is as presented below in comparing the level of use of PM for farmers for any combination of two of the three states.

$$
z=\frac{\overline{X_{1}}-\overline{X_{2}}}{\sqrt{s_{1}^{2} / n_{2}}+\sqrt{s_{2}^{2} / n_{2}}}
$$

Where $\mathrm{z}=$ standard " $\mathrm{Z}$ " distribution value $(\mathrm{z}$ calculated)

$\overline{X_{1}}=$ mean value of PM level of use for state (1) farmers

$\overline{X_{2}}=$ mean value of PM level of use for state farmers

$\mathrm{S}_{1}=$ standard deviation of sample mean value of PM level of use for state (1) farmers

$\mathrm{S}_{2}=$ standard deviation of sample mean value of PM level of use for state (2) farmers

(1) and (2) = any two combination of Ondo, Ogun and Oyo States

$\mathrm{n}_{1}=$ sample size for Ogun State (48)

$\mathrm{n}_{2}=$ sample size for Ondo State (38)

$\mathrm{n}_{3}=$ sample size for Oyo State (34)

Ordinary least squares regression was used in identifying farmers' socio-economic characteristics which influence the use of PMs. The implicit form of the regression equation is: 
$Y=f\left(X_{1}, X_{2}, X_{3}, X_{4}, X_{5}, X_{6}, X_{7}, X_{8}, X_{9}, X_{10}, U_{t}\right)$

Where $Y=$ level of use of PMs by farmers

$\mathrm{X}_{1}=$ average yearly income from farming activities $(\mathrm{N})$

$\mathrm{X}_{2}=$ farmers' age (years)

$\mathrm{X}_{3}=$ farmers' number of years of formal education

$\mathrm{X}_{4}=$ farming experience of farmer

$\mathrm{X}_{5}=$ household size

$\mathrm{X}_{6}=$ number of heads of animals kept

$\mathrm{X}_{7}=$ average number of travels by farmers outside farmers' own community per year

$\mathrm{X}_{8}=$ membership of trade/co-operative associations, dummy, 0 if farmer is not a member, 1 otherwise

$\mathrm{X}_{9}=$ mass media exposure of the farmer as indicated by number of information media being accessed

$\mathrm{X}_{\mathrm{IO}}=$ distance of farmers' farm to the nearest veterinary clinic/hospital $(\mathrm{km})$

$\mathrm{U}_{\mathrm{t}}=$ Error term assumed to be stochastic.

There was no assumption as to the regression form which gives the best fit. Four functional forms; linear, exponential, double-log and semi-log were each fitted to the data. The lead equation was selected based on statistical, economic and econometric criteria.

\section{Results and Discussion \\ Background Information}

Empirical result showed that about $50.0 \%$ of the farmers have been into livestock rearing for ten years or less. Close to $36.0 \%$ of the farmers had experience of between 11-20 years while the balance of $15.0 \%$ had been in the animal rearing and production venture for 20 years and over (Table 1). About $67.0 \%$ of the farmers had less than secondary school education. The farmers that had secondary and tertiary education were about $33.0 \%$ of the respondents. The poor level of education is a reflection of the situation obtainable in the rural areas of Nigeria [26]. About $87.5 \%$ of the respondents were male. This is probably due to the fact that household heads in Nigeria are predominantly male [26].

The livestock most frequently kept were goats and sheep. Goats were being kept by $80.0 \%$ of the sample farmers while about $51.0 \%$ of the farmers were keeping sheep. Rearing of cattle was rare especially in Ondo and Ogun States while in Oyo State; a few farmers were having cattle as part of their stock. In all, only $16.0 \%$ of sample farmers had cattle as part of the livestock being reared (Table 1).

In terms of how knowledge of PMs was transferred, $40 \%$ of the sample attributed it to their parents while $27 \%$ traced it to other farmers and friends involved in livestock rearing both within and outside their communities. Close to $14 \%$ of the respondents said they sometime receive information on medicinal uses of herbs, their preparation and administration from dreams. It is their belief that farmer's departed forefathers and
Table 1 Socio-economic Characteristics of Livestock Farmers

\begin{tabular}{lccc}
\hline $\begin{array}{l}\text { Farming experience } \\
\text { (yrs) }\end{array}$ & $\begin{array}{c}\text { No of } \\
\text { farmers }\end{array}$ & Percentage & $\begin{array}{c}\text { Cumulative } \\
\text { percentage }\end{array}$ \\
\hline $1-10$ & 59 & 49.2 & - \\
\hline $11-20$ & 43 & 35.8 & 85.0 \\
\hline $21-30$ & 18 & 15.0 & 100.0 \\
\hline Educational level & & & - \\
\hline No formal education & 26 & 21.7 & 36.7 \\
\hline $\begin{array}{l}\text { Adult literacy } \\
\text { education }\end{array}$ & 18 & 15.0 & 66.7 \\
\hline Primary school & 36 & 30.0 & 91.7 \\
\hline Secondary school & 30 & 25.0 & 100.0 \\
\hline Tertiary school & 10 & 8.3 & 87.5 \\
\hline Sex & & & 100.0 \\
\hline Male & 105 & 87.5 & - \\
\hline Female & 15 & 12.5 & - \\
\hline Types of ruminants* & & & - \\
\hline Goat & 96 & 80.0 & \\
\hline Sheep & 61 & 50.8 & 21.7 \\
\hline Cattle & 26 & & \\
\hline *Most fams kt mo tan typ of livesto &
\end{tabular}

*Most farmers kept more than one type of livestock.

guiding spirits of the community sometime reveal such to a helpless person to save human or animal live. Folkloric tales and trial and errors (local experimentation which leads to experience over years) account for $15 \%$ while the balance of $4 \%$ is due to informal training. Most of the farmers interviewed were of the opinion that traditional knowledge of uses of medicinal plants is currently under threat with the imminent exit of the older generations, who had the custody of traditional medical practice. This position is in accordance with the observation by Prance [28], that these older people have the bulk of the information on uses of plants for medicine. This, he said, calls for better focus on conserving traditional community knowledge of remedies and scientific evaluation of safety and efficacy PMs.

\section{Level of Knowledge and Utilization of PMs}

Thirty-five (35) PMs identified in the study area are shown in Table 2. The PMs listed in the table are unique medical practices based on ethno-botanical resources available in the rural areas. The necessary ingredients are locally available, free or are very cheap and are thus expected to fit the culture and the socioeconomic realities of farmers especially those that are poor. These PMs are thus potential valuable tool(s) in the design of sustainable health component of traditional animal husbandry strategies for the smallholders of Southwest Nigeria. Most of the plant sources presented in Table 2 have been studied and their active 
Table 2 Plant Medicines Identified Based on Plant Medicines Use Index

No. Plant Medicine Practice

\begin{tabular}{|c|c|c|c|c|c|c|c|}
\hline \multirow[t]{2}{*}{ No. } & \multirow[t]{2}{*}{ Plant Medicine Practice } & \multicolumn{5}{|c|}{ PMs Scores } & \multirow[t]{2}{*}{ PMUI } \\
\hline & & FU & OU & RU & ANU & NA & \\
\hline 1 & Deworming of livestock through extract of tender shoots of pineapple plant (Ananas comosus). & 42 & & 10 & 10 & 8 & 468 \\
\hline 2 & Ground garlic and ginger mixed with palm oil for curing cough. & 44 & 36 & 10 & 26 & 4 & 450 \\
\hline 3 & Feeding the juice of old sugarcane (last season's crop) as a cure for cessation of urination. & 40 & 38 & 20 & 12 & 10 & 446 \\
\hline 4 & $\begin{array}{c}\text { Treatment of sleeplessness with extract from goat weed (Ageratum conyzoides) leaves sprinkled with chewed } \\
\text { alligator pepper. }\end{array}$ & 40 & 48 & 8 & 8 & 8 & 440 \\
\hline
\end{tabular}
alligator pepper.

\begin{tabular}{lrlllllll}
\hline 5 & Feeding raw ginger mixed with table salt to cure constipation. & 40 & 30 & 26 & 8 & 16 & 430 \\
\hline 6 & Control of body lice through application of leaf extract of bullock's heart (Annona recticulata). & 32 & 40 & 26 & 6 & 16 & 426 \\
\hline 7 & Use of root and stem extract of snakewort in stimulating uterine contraction and parturition in pregnant & 40 & 21 & 30 & 18 & 11 & 421 \\
& animals.
\end{tabular}

\begin{tabular}{llllllll}
\hline 8 & Use of snakewort (Aristolocia bracteata) leaf extract as antidote to snake poison, scorpion bite and \\
antihelmintic.
\end{tabular}

\begin{tabular}{lccccccc}
\hline 9 & Use of extract of cashew tender roots in curing persistent cough. & 30 & 40 & 21 & 10 & 19 & 412 \\
\hline 10 & Use of Euphorbia hirta leaves in the treatment of diarrhoea and dysentery. & 26 & 36 & 28 & 20 & 10 & 408 \\
\hline 11 & Treatment of physical weakness by feeding raw ginger and molasses paste to an animal once daily. & 40 & 35 & 12 & 20 & 13 & 394 \\
\hline 12 & Use of Euphorbia hirta leaves pounded and mixed with water as cure for constipation. & 30 & 22 & 29 & 20 & 19 & 384 \\
\hline 13 & Feeding gur (juice of sugarcane in crystallized form) to cure cessation of urination. & 29 & 16 & 36 & 24 & 15 & 380 \\
\hline 14 & Feeding of gum of tamarind and banana together with straw to improve lactation on first delivery. & 21 & 37 & 19 & 26 & 17 & 379 \\
\hline 15 & Application of extract of wide cucumber (Mormodica charalia) as purgative and antidote to some gastro- & 24 & 26 & 31 & 22 & 17 & 378 \\
& & & & & & & \\
\hline
\end{tabular}

\begin{tabular}{lllllllll}
\hline 16 & Use of dog's liver plant (Kelanchoe crenata) leaf extract in treating general debility and stiffness of joints. & 18 & 31 & 36 & 20 & 15 & 377 \\
\hline 17 & An infusion of hairy spurge or Australian asthma herb (Euphorbia hirta) given to animals for increased & 17 & 38 & 25 & 24 & 16 & 376
\end{tabular}
lactation.

\begin{tabular}{lccccccc}
\hline 18 & Use of the root and bark of Radish plant (Moringa pterygosperma) in treatment of fever and mouth sores. & 17 & 31 & 34 & 26 & 12 & 375 \\
\hline 19 & Application of ground seeds of wild cucumber in treatment of jaundice. & 26 & 19 & 28 & 37 & 10 & 374 \\
\hline 20 & Cultivation of Ocimum gratissimum and Cymbopogon citrates round livestock houses to serve as repellents to & 26 & 31 & 20 & 14 & 29 & 371 \\
insects.
\end{tabular}

\begin{tabular}{llllllll}
\hline 21 & Crushed back of Wild Oliver applied to sores of domestic animals. & 20 & 26 & 32 & 19 & 23 & 361 \\
\hline 22 & Use of Ocimum gratissimum leaf and whole plant part in treatment of diarrhoea. The animal drinks the cold & 16 & 20 & 40 & 36 & 8 & 360 \\
infusion extract twice daily.
\end{tabular}

\begin{tabular}{lrlllllll}
\hline 23 & An infusion of crushed fruit of wild Oliver given to animals to cure "bloody diarrhoea". & 18 & 24 & 30 & 32 & 16 & 356 \\
\hline 24 & Curing loose motion through feeding of leaves of Musa acuminata mixed with the ash of dried walnut. & 12 & 28 & 41 & 20 & 19 & 354 \\
\hline 25 & Use of Ageratum conyzoides in dressing sores and wounds. & 18 & 27 & 29 & 18 & 28 & 349 \\
\hline 26 & Use of mustard oil paste to cure gingivitis. & 16 & 24 & 32 & 28 & 20 & 348 \\
\hline 27 & Using a paste of lime juice, butter and few seeds (10-12) of black pepper to cure asthma/anorexia. & 16 & 28 & 14 & 32 & 29 & 339 \\
\hline 28 & Curing digestive troubles through feeding of rashun, lime juice and butter wrapped in banana leaves & 11 & 28 & 40 & 10 & 31 & 338 \\
\hline 29 & Applying few drops of juice of immature Leucus aspera mixed with table salt at the corner of the eyes to & 14 & 26 & 30 & 22 & 28 & 336 \\
& cure cessation of defecation & & &
\end{tabular}

30 Extract of roots of wild Oliver (Ximenia americana) with that of Annona senegalensis or Annona. chrysophylla in $\begin{array}{lllllll}10 & 28 & 31 & 29 & 22 & 335\end{array}$ the treatment of sleeping sickness.

\begin{tabular}{lcccccccc}
\hline 31 & Coating the area of pain with molasses and ash of Harrisonia abyssiniea to cure haemorrhagic septicemia. & 22 & 12 & 30 & 30 & 26 & 334 \\
\hline 32 & Pouring of raw mustard oil through the nostril of an animal to stimulate appetite. & 18 & 22 & 31 & 12 & 37 & 332 \\
\hline 33 & Curing bloat through dilution of dusts of turmeric in indigenous smoking pipe and feeding it to the animal. & 14 & 26 & 24 & 21 & 32 & 320 \\
\hline 34 & $\begin{array}{c}\text { Application of Solanum nodiflorum wrapped in banana leaves and heated in hot ash. The juice is squeezed } \\
\text { on to the sore and applied twice daily. }\end{array}$ & $\begin{array}{l}26 \\
30\end{array}$ & 31 & 23 & 10 & 299 \\
\hline 35 & Use of aqeous leaf extract of Hagenia abyssinica and Mollugo hirta as anthelmintic in vitro. & 16 & 14 & 24 & 20 & 46 & 294 \\
\hline
\end{tabular}

$\mathrm{NB}: \mathrm{FU}=$ frequently used, $\mathrm{OU}=$ occasionally used, $\mathrm{RU}=$ rarely used, $\mathrm{ANU}=$ aware but not used, NA $=$ Not aware 
ingredients are scientifically associated with the effects that farmers claim they produce both in Africa and other countries $[18,27]$.

Table 3 presents information on the level of knowledge of PMs among the sampled farmers. The table shows that the sum total of farmers who claimed to know the remedies presented in Table 2 (summation of frequently used (FU), occasionally used (OU), rarely used (RU) and aware but not used (ANU)) was 3,549 while the sum total of farmers who claimed not to know the remedies (summation of not aware (NA)) was 651. The mean number of farmers who claimed to know the 35 remedies in Table 2 (3,549 divided by 35) was 101.4 while the mean number of farmers who were not aware of the remedies (651 divided by 35 ) was 18.6. These mean values indicate that about 101 farmers out of 120 acknowledged that they know the remedies. This represents about $84.5 \%$ of the sampled farmers.

Going by PMUIs, the PMs contained in Table 2 were categorized as poorly-used, moderately-used and highlyused. The PMUIs ranged between 294 and 468. On a fairly equal interval scale, about $31.0 \%$ of the PMs were poorly-used while $43.0 \%$ and $26.0 \%$ were regarded as moderately- and highly-used, respectively (Table 4). These findings are similar to those of Islam and Kashem [27]. The fact that none of the PMs had a PMUI of zero indicates that PMs have not been completely discarded by farmers in spite of the availability of western veterinary drugs. This may mean that they probably benefit the farmers. The PMs that are poorly used by farmers may have been so used because they were known to a restricted number of farmers in the locality. It is also possible that certain PMs were avoided by farmers because of repeated poor efficacy or higher complexity in both preparation and use. Also, poor use of a PM may arise from the availability of modern means of treatment that are more convenient than the corresponding PM [27].

The attributes of a new practice that may give rise to poor adoption are lower relative advantage, higher complexity and lower compatibility [29]. The PMs in the poorly-used category having lower PMUI and lower ranks are probably characterized by these afore-stated attributes and are probably on their ways to extinction in traditional livestock health management by farmers.

Table 3 Farmers' Knowledge of the Thirty-five Plant Medicines

\begin{tabular}{lll}
\hline & Had Knowledge & Lacked Knowledge* \\
\hline Total & 3549 & 651 \\
\hline Mean & 101.4 & 18.6 \\
\hline Percent & 84.5 & 15.5 \\
\hline
\end{tabular}

* Computed from NA (Not Aware) column of Table 2
On the other hand, the highly used PMs may be relatively advantageous, less complex and more compatible with the needs and realities of the farmers. Farmers may also have been utilizing these practices because of inaccessibility to the corresponding modern remedial measures [27].

Table 5 reveals that about $35.0 \%$ of farmers used the PMs moderately while only $20.0 \%$ used PMs highly. The remaining $45 \%$ of the farmers used PMs poorly. This finding attests to a significant knowledge and use of the PMs among rural livestock farmers in the study area. Also, no individual respondent recorded a zero score in the use of PMs. This implies that the PMs probably offer some positive benefits to users.

\section{Comparison of PM Level of Use between States}

The mean PM level of use for Ogun, Ondo and Oyo States were 67, 56 and 59; respectively. The results of the pair-wise comparison by z-test (Table 6) showed that there was a significant difference in mean PM level of use between Ogun and Ondo States as was also the case between Ogun and Oyo States at the 5\% level of significance. However, there was no significant difference in PM level of use between Ondo and Oyo States. The implication of these results is that individual farmer's extent of use of PM was higher in Ogun State compared with Ondo and Oyo States. A deliberate regional policy to encourage farmers' use of PMs in Southwest Nigeria should therefore commence in Ondo and Oyo States.

A further comparison of PMUI across the three states is presented in Table 7. The table shows that, among the high-users of PMs, Ogun State accounted for 66.7\%, while Ondo and Oyo States accounted for $20.8 \%$ and $12.5 \%$, respectively.

\section{Determinants of PMs' Utilization}

Upon critical evaluation of the results of the various functional forms, the double-log form of the regression model was chosen as the lead equation. The results which reveal the level of variation in extent of use of PMs (Y) explained by farmer-specific independent (explanatory) variables is presented in Table 8 .

The model's $\mathrm{R}^{2}$ means that the postulated socio-economic variables were jointly responsible for about $64.0 \%$ of the observed variations in the utilization of PMs. The results reveal a positive significant relationship between farmer's age, household size, distance of farmers' farm to the nearest veterinary clinic/hospital and the average number of times a farmer has travelled outside his/her locality in a year; and the utilization of PMs. These variables were significant at the 5\% level. Higher values of these variables will translate to higher level of PMs' utilization. 
Table 4 Classification of Plant Medicines based on Plant Medicines Use Index

\begin{tabular}{lcc}
\hline Categories based on Plant Medicines Use Index & Number of Plant Medicines in each category & Percentage \\
\hline Poorly-used (294-351) & 11 & 37.4 \\
\hline Moderately-used (352-410) & 15 & 42.9 \\
\hline Highly-used (411-468) & 9 & 25.7 \\
\hline Total & 35 & 100.0 \\
\hline
\end{tabular}

The positive relationship between age and utilization of PMs can be explained from the perspective of older farmers being custodians of knowledge on the preparation and application of PMs [30]. Also, the longer years of acquaintance with PMs will enable older farmers to be sure of the efficacy or otherwise of some of the PMs and the conditions to be fulfilled in their preparation to enhance efficacy [30].

Travelling education broadens one's intellectual and information horizons through extended contact with outside knowledge and information sources [27]. A farmer that travels more often has a greater opportunity of meeting different persons or receiving information from sources unavailable in his/her community. This makes it possible for such a farmer to have knowledge of PMs and modern veterinary services available elsewhere. $\mathrm{S} /$ he is therefore able to compare and select a combination of PMs and modern veterinary practices that is more cost-effective. This may be the reason for the observed positive relationship between the average number of times a farmer has travelled outside his/her locality and utilization of PMs.

Household size increases brought about an increased utilization of PMs probably because the higher the household size, the higher the household expenditure. For a poor farmer, the competition for funds between household needs and livestock health maintenance may elicit the response that the farmer holds on to the cheaper PMs to free sufficient financial resources for meeting household expenditures. The regression results indicate that a $1 \%$ increase in each of farmer's age, household size and average number of times a farmer has travelled outside his/her locality will result in $14.4 \%$, $10.6 \%$ and $11.2 \%$, respectively in the level of use of PM. Similarly, a $1 \%$ increase in the distance of farmers' farm

Table 5 Level of Utilization of Plant Medicines

\begin{tabular}{lcc}
\hline Categories & \multicolumn{2}{c}{ Respondents } \\
\cline { 2 - 3 } & Number & Percent \\
\hline Low user (55-90) & 54 & 45.0 \\
\hline Moderate user (91-126) & 42 & 35.0 \\
\hline High user (127-162) & 24 & 20.0 \\
\hline Total & 120 & 100.0 \\
\hline
\end{tabular}

Mean $=66.849$ Standard Deviation $=28.489$ to the nearest veterinary clinic/hospital will result in $12.5 \%$ increase in the use of PM.

Variables that showed significant negative relationships with the utilization of PMs were farm income and heads of livestock kept. For these variables, the higher their values, the lower the utilization of PMs. From the results, a $1.0 \%$ increase in farm income translates to a $20.0 \%$ decrease in the utilization of PMs. Likewise; a $1.0 \%$ increase in the heads of livestock kept will result in 19.0\% decrease in the utilization of PMs.

The negative relationship between farmer's income and utilization of PMs is explainable from the view point that a farmer's economic position will influence his access to modern veterinary services in rearing and managing livestock health. The higher the income, the higher is the access to veterinary drugs. Higher economic status may therefore reduce farmer's use of PMs $[20,30]$. Also, increase in the number of animals kept led to reduced utilization of PMs probably because the higher the number of animals, the higher the tendency to rear the livestock on commercial basis and hence the higher the use of purchased inputs which invariably include veterinary drugs.

\section{Table 6 Comparison of Mean Plant Medicines Level of Use across States}

\begin{tabular}{lccccc}
\hline Locations & \multicolumn{3}{c}{$\begin{array}{c}\text { Mean Plant Medicines Level } \\
\text { of Use }\end{array}$} & $\mathbf{Z}$ value & P value \\
\hline \multicolumn{7}{c}{ Ogun } & Ondo & Oyo \\
\hline Ogun Versus Ondo & $67(18.4)$ & $56(22.5)$ & - & 11.08 & 0.044 \\
\hline Ogun Versus Oyo & $67(18.4)$ & - & $59(26.2)$ & 13.62 & 0.041 \\
\hline Ondo Versus Oyo & & $56(22.5)$ & $59(26.2)$ & 5.26 & 0.112 \\
\hline
\end{tabular}

*Values in parentheses are standard errors

Table 7 Comparison of Level of Utilization of Plant Medicines

\begin{tabular}{llllllll}
\hline \multirow{2}{*}{ States } & \multicolumn{2}{c}{ Category } & \multicolumn{2}{c}{ Category } & \multicolumn{2}{c}{ Category } & \multirow{2}{*}{ Total } \\
\cline { 2 - 6 } & Low & Users & \multicolumn{2}{c}{ Moderate Users } & \multicolumn{2}{c}{ High Users } & \\
\cline { 2 - 6 } & No & $\%$ & No & & No & $\%$ & \\
\hline Ogun & 13 & 24.1 & 19 & 45.2 & 16 & 66.7 & 48 \\
\hline Ondo & 24 & 44.4 & 09 & 21.4 & 05 & 20.8 & 38 \\
\hline Oyo & 17 & 31.5 & 14 & 33.3 & 03 & 12.5 & 34 \\
\hline Total & 54 & 100.0 & 42 & 100.0 & 24 & 100.0 & 120 \\
\hline
\end{tabular}


Table 8 Multiple Regression Results

\begin{tabular}{llll}
\hline Variable & Coefficient & $\begin{array}{l}\text { Standard } \\
\text { Error }\end{array}$ & $\begin{array}{l}\text { Level of } \\
\text { significance }\end{array}$ \\
\hline Constant & -101.41 & 726 & \\
\hline Average yearly income from farming activities & -20.29 & 4.40 & $1 \%$ \\
\hline Farmers' age (years) & 14.35 & 6.33 & $5 \%$ \\
\hline Farmers' number of years of formal education & -6.45 & 12.21 & Not significant \\
\hline Farming experience of farmer & 3.44 & 7.84 & Not significant \\
\hline Household size & 10.55 & 4.26 & $5 \%$ \\
\hline Number of animals kept & -19.21 & 5.11 & $1 \%$ \\
\hline Average number of travels by farmers outside farmers' own community per year & 11.21 & 4.92 & $5 \%$ \\
\hline Membership of trade/co-operative associations & -7.24 & 6.81 & Not significant \\
\hline Mass media exposure of the farmer as indicated by number of information media being & -4.87 & 2.96 & Not significant \\
\hline accessed & & 12.52 & 4.77 \\
\hline Distance of farmers' farm to the nearest veterinary clinic/hospital $(\mathrm{km})$ & $5 \%$
\end{tabular}

Dependent variable is the natural logarithms of the level of use of Plant Medicines. The independent variables are all in natural logarithms. $R^{2}=0.642 ; R^{-2}=0.629 ; F=36.21$

\section{Conclusion and Recommendations}

This study sets out to determine the PMs used in the study area and their level of utilization among livestock farmers. It was also intended to compare the level of utilization of PMs across the three states and identify the socio-economic factors influencing farmer's utilization of PMs.

A total of 35 PMs were identified in the study area. There was considerable knowledge about these PMs among the livestock farmers. In spite of this, most $(80.0 \%)$ of the farmers used PMs to poor/moderate extent. The level of utilization of PMs varied between the three states, with Ogun State taking the lead. Six socio-economic variables influenced the utilization of PMs significantly. These are farmer's age, household size, distance of farmers' farm to the nearest veterinary clinic/hospital and extent of travels; which had positive effects; and farm income and heads of livestock; which had negative effects.

There was significant knowledge about PMs in the study area and, due to continuing operations of the farmers at subsistence level; PMs will most likely continue to be relevant for livestock health management. There is a need to preserve local knowledge of PMs and this could be achieved through Farmer Field Research in which university researchers and farmers jointly carry out research about PMs on farmers' farms. This will enable groups of farmers and researchers, through a discovery learning process, find out about the efficacies of various PMs while the younger farmers and university researchers learn from the older farmers who are regarded as custodians of knowledge about PMs. This process will facilitate the documentation of PMs with proven efficacies.

\section{Consent}

Verbal informed consent was obtained from the participants of this study

\section{Author details}

'Department of Agricultural Economics and Extension, The Federal University of Technology, Akure, Nigeria. ${ }^{2}$ Department of Animal Production and Health, The Federal University of Technology, Akure, Nigeria. ${ }^{3}$ Department of Crop, Soil and Pest Management, The Federal University of Technology, Akure, Nigeria.

\section{Authors' contributions}

TE conceived the study, gathered and reviewed literature, participated in the field work and manuscript drafting, AE participated in literature gathering and review, field work and manuscript drafting, AN and OP participated in the field work. All authors read and approved on the manuscript.

\section{Competing interests}

The authors declare that they have no competing interests.

Received: 9 June 2011 Accepted: 12 January 2012

Published: 12 January 2012

\section{References}

1. NBS: Annual Abstract of Statistics. A publication of the National Bureau of Statistics, Nigeria; 2007, 352

2. Okunmadewa FY, Mafimisebi TE, Fateru OO: Resource use efficiency of commercial livestock farmers in Oyo State, Nigeria. Trop Ani Prod Invests 2002, 5(1):47-57.

3. Central Bank of Nigeria: 2005, 154p, Annual Report and Statement of Accounts for the year Ended 31st December.

4. UNICEF: Strategy for Improved Nutrition of Children and Women in Developing Countries. 1990, 71, UNICEF Policy Review Paper.

5. Shaib B, Adedipe NO, Aliyu A, Jir MM: Integrated Agricultural Production in Nigeria: Strategies and Mechanisms for Food Security. National Agricultural Research Project, Monograph 1997, No.5, 187p.

6. Olalokun EA: Sustainable Animal Production for Self-sufficiency in the $21^{\text {st }}$ Century. In Animal Science at the University of Ibadan A Commemorative Brochure of Anniversary Home-coming Celebrations Edited by: Egbunike GN 1998, 45.

7. Mafimisebi TE, Onyeka UP, Ayinde IA, Ashaolu OF: Analysis of farmerspecific socio-economic determinants of adoption of modern livestock management technologies by farmers in Southwest, Nigeria. J Food Agric and Env 2006, 4(1):183-186. 
8. Okojie JA: The role of government and Universities of Agriculture in improving animal production and consumption in Nigeria. J Ani Sci 1999, 2(2):21-30

9. Phillip D, Nkonya E, Pender J, Oni OA: Constraints to increasing agricultural productivity in Nigeria: A review International Food Research Institute, Nigeria Strategy Support Program (NSSP), September 2009, Background paper No NSSP006., http://www.ifpri.org/sites/default/files/ publications/nsspbp06.pdf (accessed 04/05/2011).

10. Aletor VA, Osho IB, Awoniyi TAM: Medicinal Plants of Animal Production and Health Importance. In Medicinal Plants in Agriculture: The Nigerian Experience. Edited by: Onibi GE, Agele SO, Adekunle VAJ, Olufayo MO. proceedings of the Akure-Humboldt Kellog/3RD SAAT Annual Conference; 2007:XVI-XXXV

11. Mc Corkle CM: An introduction to ethno-veterinary research and development.Edited by: Ethnobio J 1986, 6(1):129-149.

12. Mc Corkle CM: Back to the future: Lessons from ethno-veterinary RD \& E for studying and applying local knowledge. Agric.\& Human Values. 1995, 12(2):52-80.

13. Mafimisebi TE, Technology Adoption and Economic Development: Trajectories from the African Agricultural Industry. In Nanotechnology and Microelectronics, Global Diffusion, Economics and Policy. Edited by: Ekekwe N. IGI Global publishers, New York, USA; 2010:298-313.

14. Okunmadewa FY: Livestock industry as a tool for poverty alleviation. Ani Sci 1999, 2(2):31-38

15. Suleiman H: Policy Issues in Pastoral Development. Paper presented at the National Conference on Pastoralism in Nigeria held at the National Animal Production Research Institute, Ahmadu Bello University, Zaria, Nigeria. 1988

16. Williams CE, Williams SKT: Extension Services in Livestock Production Sector in Nigeria. Nig J Agric Dev 1991, 1(1):1-13.

17. Mathias E, Mc Corkle CM: Animal Health. In Biotechnology: Building on Farmers' Knowledge. Edited by: Bunders J, Haverkort B, Aiemstra W. oLondon and Basingstoke: Macmillan Education Ltd; 1996:

18. Sofowora A: Medicinal Plants and Traditional Medicine in Africa. Spectrum Books Limited Ibadan 1993, 289.

19. Ogunlela VB: Husbandry and cultivation of medicinal plants. In Medicinal Plants in Agriculture: The Nigerian Experience, proceedings of the AkureHumboldt Kellog/3RD SAAT Annual Conference Edited by: Onibi GE, Agele SO, Adekunle VAJ, Olufayo MO 2007, XV-XXI.

20. Mafimisebi TE, Oguntade AE: Preparation and Use of Plant Medicines for Farmers' Health in Southwest Nigeria: Socio-cultural, Magico-religious and Economic Aspects. Journal of Ethnobiology and Ethnomedicine 2010, $6: 1$

21. Ghosh RK, Goswami A, Mazumdar AK: Adoption behaviour of the dairy farmers in relation to artificial insemination in co-operative farming system. Livestock Research for Rural Development 2005, 17, Art. Number 35. http://www.Irrd.org//rrd17/3/ghos17035.htm (accessed 17th December 2011).

22. Goswani A, Roy N, Mazumdar AK, Duttagupta R: Factors related with adoption behaviour of the livestock owners about artificial insemination. J Interacademeia 2000, 4(2):304-309.

23. Fakoya EO, Ojo DK, Oyesola OB: Categorization of farmers in relation to use of sustainable land management practices in Ondo State, Nigeria. Asset, series A 2002, 2(2):29-37.

24. Adesina AA, Chianu J: Determinats of farmers' adoption and adoption of alley farming agro-forestry technology in Nigeria. In Natural Resource Management in African Agriculture: Understanding and Improving Current Practices. Edited by: Barret CB. International Centre for Research in Agroforestry (ICRAF); 2002:48-57.

25. Ghosh RK, Goswani A, Mazuumdar AK: Adoption behaviour of dairy farmers in relation to artificial insemination in co-operative farming system. J Interacademeia 2005, 9(1):250-258

26. NBS: Nigeria Core Welfare Indicators National, Bureau of Statistics. 2006 http://www.nigerianstat.gov.ng/nbsapps/nada/index.php?page=catalog (accessed 17th December 2011).

27. Islam MM, Kashem MA: Farmers' use of ethno-veterinary medicine (EVM) in the rearing and management of livestock: An empirical study in Bangladesh. J Sus Agric 1999, 13(4):39-56.

28. Prance GT: Ethnobotany and the future of conservation. Biologist 2000 47(2):65-68
29. Rogers EM: Diffusion of Innovations. New York, 1995, The Free Press; Fourth.

30. Mafimisebi TE, Oguntade AE: Health infrastructure inequality and ruralurban utilization of orthodox and traditional medicines in farming households: A case study of Ekiti State, Nigeria. In "Health Management Different Approaches and Solutions", InTech Open Access Publishers, Rijeka, Croatia Edited by: Krzysztof Śmigórski 2011, 197-214[http://www.intechopen. com/source/pdfs/24988/InTech-Health_infrastructure_inequality_and_rural_ urban_utilization_of_orthodox_and_traditional_medicines_in_farming_ households_a_case_study_of_ekiti_state_nigeria.pdf].

doi:10.1186/1746-4269-8-2

Cite this article as: Mafimisebi et al:: Local knowledge and socioeconomic determinants of traditional medicines' utilization in livestock health management in Southwest Nigeria. Journal of Ethnobiology and Ethnomedicine 2012 8:2

\section{Submit your next manuscript to BioMed Central and take full advantage of:}

- Convenient online submission

- Thorough peer review

- No space constraints or color figure charges

- Immediate publication on acceptance

- Inclusion in PubMed, CAS, Scopus and Google Scholar

- Research which is freely available for redistribution

Submit your manuscript at www.biomedcentral.com/submit
C Biomed Central 